\title{
Pengaruh LKS Berbasis Problem Solving untuk Meningkatkan Keterampilan Berpikir Kreatif Siswa
}

\author{
Lisa Rahma Putri*, Ratu Beta Rudibyani, Emmawaty Sofya \\ Program Studi Pendidikan Kimia, Universitas Lampung, Indonesia \\ Corresponding author: lisarahmaputri05@gmail.com
}

\begin{abstract}
The Effect of Problem Solving Based Worksheet to Improve Creative Thinking Skills Students. This research aims to describe the effect of using problem solving based worksheet to improve students creative thinking skills in electrolyte and non-electrolyte solution topic. This research uses quasi experiment method with Non-Equivalent Pretest Posttest Control Group Design. The population in this research was class X Senior high school $N 13$ Bandarlampung. The sampel used was cluster random sampling, the class $X$ MIPA 1 was the experimental class and X MIPA 5 was the control class. To prove the students worksheet based on problem solving is influential in improving students creative thinking skills, then a measure of influence effect size. The result of data analysis showed that students creative thinking skills had a large influence on the experimental class compared to the control class. Based on the results of the research it can be concluded that problem solving based worksheet has large influence in improving students creative thinking skills in electrolyte and non-electrolyte solution topic.
\end{abstract}

Keywords: problem solving based student worksheet, creative thinking skills, electrolyte and non-elektrolyte solution.

\begin{abstract}
Abstrak: Pengaruh LKS Berbasis Problem Solving untuk Meningkatkan Keterampilan Berpikir Kreatif Siswa. Penelitian ini bertujuan untuk mendeskripsikan pengaruh LKS berbasis Problem Solving untuk meningkatkan kemampuan berpikir kreatif siswa pada materi larutan elektrolit dan non elektrolit. Penelitian ini menggunakan metode quasi eksperiment dengan desain Non-Equivalent Pretest Posttest Control Group Design. Populasi dalam penelitian ini adalah siswa kelas X SMAN 13 Bandarlampung. Pengambilan sampel menggunakan cluster random sampling, diperoleh kelas X MIPA 1 sebagai kelas eksperimen dan X MIPA 5 sebagai kelas kontrol. Untuk membuktikan LKS berbasis problem solving berpengaruh dalam meningkatkan keterampilan berpikir kreatif siswa maka dilakukan uji pengaruh (Effect Size). Hasil analisis data diperoleh bahwa keterampilan berpikir kreatif siswa berpengaruh besar pada kelas eksperimen dibandingkan kelas kontrol. Berdasarkan hasil penelitian dapat disimpulkan bahwa LKS berbasis problem solving memiliki pengaruh besar dalam meningkatkan keterampilan berpikir kreatif siswa pada materi larutan elektrolit dan non elektrolit.
\end{abstract}

Kata kunci: LKS berbasis problem solving, keterampilan berpikir kreatif, larutan elektrolit dan non elektrolit. 


\section{PENDAHULUAN}

Kini kita telah memasuki abad 21, abad dimana berbagai informasi dapat diperoleh oleh semua orang di penjuru dunia tanpa terkecuali. Abad 21 menuntut individu bukan hanya memiliki pengetahuan saja namun harus memiliki kecapakan atau keterampilan yang baik. Dimana salah satu keterampilan abad 21 yang dapat dikuasai melalui pendidikan ialah learning and innovation skills $4 \mathrm{C}$ menurut Nasional Education Association (2002) learning and innovation skills terdiri dari 4 aspek, yaitu critical thinking (berpikir kritis), communication (komunikasi), collaboration (kolaborasi/ kerjasama), dan creativity (kreativitas).

Kurikulum 2013 merupakan gerbang awal untuk memasuki pendidikan di abad 21. Pendidikan abad 21 menuntut siswa untuk menyelesaikan masalah melalui ilmu pengetahuan yang mereka peroleh serta memberi kesempatan bagi siswa untuk dapat mengambil keputusan berdasarkan bukti yang diperoleh dari proses ilmiah dalam menyelesaikan masalah pada kehidupan kesehariannya (Wijaya, 2016). Peng-gunaan kurikulum 2013 yang memasuki abad 21 juga mengubah paradigma belajar dunia, yakni paradigma teaching menjadi learning. Kini bukan lagi guru yang menjadi pusat belajar, namun siswa yang menjadi pusat belajar. Peranan guru dalam kurikulum 2013 diharapkan tidak hanya menjadi sumber belajar melainkan juga sebagai fasilitator dalam seluruh kegiatan pembelajaran (Hidayat, 2013).

Keterampilan abad 21 yang dikembangkan dari penerapan kurikulum 2013 diharapkan dapat mengembangkan keterampilan berpikir siswa, khususnya keterampilan berpikir kreatif. Sumber daya manusia yang kreatif melalui gagasan cemerlangnya dipastikan mampu menyelesaikan permasalahan yang dihadapi di era globalisasi abad 21. Keterampilan berpikir kreatif akan mudah dilatihkan apabila siswa diberikan permasalahan berdasarkan pengalaman yang mereka peroleh atau permasalahan yang timbul dalam kehidupan seharai-hari.

Keterampilan berpikir kreatif merupakan keterampilan berpikir untuk menghasilkan ide-ide baru, ide-ide yang berguna, dan ide-ide alternatif yang dapat digunakan untuk memecahkan masalah (Abidin, 2016). Berpikir kreatif merupakan suatu kegiatan eksplorasi untuk melahirkan ide-ide baru yang berbeda dengan yang sudah ada yang dapat digunakan untuk membantu siswa dalam memberikan suatu keputusan yang berkualitas dalam menyelesaikan masalah-masalah yang ada dalam kehidupan sehari-hari (Munandar, 2014). Kemampuan berpikir kreatif berkenaan dengan kemampuan meng-hasilkan atau mengembangkan sesuatu yang baru, yaitu sesuatu yang tidak biasa yang berbeda dari ide-ide yang dihasilkan kebanyakan orang (Muzaki, 2014).

Keterampilan berpikir kreatif bisa dilatih dan dikembangkan, kemudian diintegrasikan dalam ber-bagai mata pelajaran yang memungkin-kan untuk pengembangan berpikir tersebut. Keterampilan berpikir kreatif memiliki lima indikator keterampilan, yaitu indikator keterampilan berpikir lancar (fluency), indikator keterampilan berpikir luwes (flexibility), indikator ke-mampuan berpikir orisinil (originality), indikator kemampuan elaboratif (elaboration), dan indikator keterampil-an berpikir evaluatif (evaluation) (Munandar, 2014). Oleh karena itu keterampilan berpikir kreatif perlu diintegrasikan dalam berbagai mata pelajaran, salah satunya adalah kimia. Kimia sebagai salah satu cabang IPA dalam proses pembelajarannya tidak hanya untuk menguasai pengetahuan kimia sebagai produk, tetapi juga untuk menguasai sikap ilmiah dan penerapan kimia dalam kehidupan sehari-hari (Salirawati, 2010). 
Pembelajaran yang menuntut siswa menjadi problem solver diperlukan suatu media pembelajaran yaitu salah satunya media Lembar Kerja Siswa (LKS). LKS adalah salah satu bahan ajar yang membantu dalam proses kegiatan pembelajaran, di dalamnya terdapat materi secara singkat, tujuan pembelajaran, petunjuk mengerjakan atau instruksi, percobaan untuk membuktikan teori atau konsep, dan sejumlah pertanyaan yang harus dijawab siswa sehingga siswa dapat mem-perluas dan memperdalam materi yang dipelajari (Depdiknas, 2008).

LKS merupakan salah satu jenis media pembelajaran berupa perangkat belajar yang digunakan untuk mem-bantu guru dalam menyampaikan pesan dan materi pelajaran kepada siswa secara efektif dan efisien (Hardianto, 2012). Penggunaan LKS diharapkan dapat membantu siswa dalam pembelajaran kimia yang berorientasi pada proses dapat tercapai. Pengunaan LKS yang dikembangkan dapat membuat siswa menjadi ber-peran secara aktif (Celikler, 2010).

Model Solusi Masalah atau Problem Solving adalah model pembelajaran yang menerapkan pola pemberian masalah atau kasus kepada siswa untuk diselesaikan. Masalah atau kasus itu tentu disesuaikan dengan materi bidang studi yang menjadi pusat belajar. Masalah atau kasus tersebut diberikan kepada siswa untuk diselesaikan secara individu atau berkelompok. Masalah atau kasus yang diberikan kepada siswa dapat berupa masalah rekayasa (buatan) maupun masalah nyata yang alami dihadapi siswa (Muliawan, 2016). Problem solving akan meningkatkan daya intelektual dalam memecahkan per-masalahan yang sulit karena siswa diberi kesempatan untuk mengeksplorasikan dirinya dengan meng-kombinasikan pengetahuan yang telah dimilikinya yaitu declarative, procedural, conditional (Caprioara, 2015). Salah satu kelebihan model pem-belajaran problem solving yaitu dapat merangsang perkembangan kemampuan berpikir kreatif siswa. Atas da-sar tersebut maka perlu digunakan LKS yang dapat menuntun siswa agar dapat memecahkan permasalahan se-cara kreatif. Di dalam mempelajari ilmu kimia, pengetahuan bukanlah tujuan utama, melainkan hanya sebagai suatu media untuk mengembang-kan ke-terampilan berpikir (Fadiawati, 2014).

Berdasarkan hasil observasi pendahuluan di SMA Negeri 13 Bandarlampung dengan guru bidang studi kimia, bahwa pada proses pembelajaran kimia di SMA tersebut sudah mengarahkan siswa untuk memperoleh pengertahuan dan konsep materi yang diajarkan namun guru kurang melatih keterampilan berpikir kreatif untuk menghadapi dan memecahkan suatu masalah. Ke-terampilan berpikir kreatif siswa dapat dilatih melalui penggunaan LKS berbasis Problem Solving. LKS berbasis Problem Solving ini akan merangsang pengembangan kemampuan berpikir siswa secara kreatif dan menyeluruh, karena dalam proses pembelajarannya siswa fokus kepada permasalahan dalam rangka mencari pemecahannya. LKS berbasis Problem Solving diharapkan dapat melatih siswa dalam memecahkan masalah ilmiah, merumuskan hipotesis, merancang suatu eksperimen untuk menguji hipotesis dan mengambil suatu kesimpulan dari sekumpulan data yang diperoleh siswa dari pembelajaran kimia, sehingga siswa dapat melatih ke-terampilan berpikir kreatif.

Berdasarkan uraian yang telah dikemukakan di atas, maka dilakukan penelitian dengan judul "Pengaruh LKS Berbasis Problem Solving Untuk Meningkatkan Keterampilan Berpikir Kreatif Siswa". Penenlitian ini ber-tujuan untuk mendeskripsikan pengaruh LKS berbasis problem solving untuk meningkatkan keterampilan berpikir kreatif siswa. 


\section{METODE}

Metode penelitian yang digunakan adalah salah satu metode penelitian menurut Fraenkel (2012) yaitu quasi experiment dengan desain non-equivalent pretest-postest control group design. Populasi dalam penelitian ini adalah seluruh siswa kelas X MIPA SMA N 13 Bandarlampung Tahun pelajaran 2018-2019 yang tersebar dalam enam kelas. Penentuan sampel menggunakan teknik cluster random sampling, diperoleh sampel yaitu kelas X MIPA 1 sebagai kelas eksperimen dan kelas X MIPA 5 sebagai kelas kontrol.

Jenis data dalam penelitian ini adalah data primer, yang berupa data hasil tes sebelum belajar (pretes) dan hasil tes setelah belajar (postes) siswa, serta data pendukung yang berupa lembar observasi keteralaksanaan pembelajaran menggunakan LKS berbasis problem solving dan data angket respon siswa terhadap penggunaan LKS berbasis problem solving. Sumber data dari penelitian ini adalah seluruh siswa-siswi kelas kontrol dan kelas eksperimen.

Uji kelayakan instrumen tes (soal pretes dan soal postes) dilakukan dengan uji validitas dan reliabilitas. Uji validitas dan reliabilitas dilakukan dengan memberikan soal pretes-postes kepada siswa yang sudah pernah menerima materi larutan elektrolit dan non elektrolit. Analisis data dilakukan dengan software SPSS versi 17 for Windows. Validitas soal ditentukan dari perbandingan nilai $r_{\text {tabel }}$ dan $r_{\text {hitung. }}$. Kriterianya adalah jika $r_{\text {tabel }}<r_{\text {hitung }}$ maka soal dikatakan valid. Reliabilitas ditentukan menggunakan Cronbach's Alpha. Kriteria derajat reliabilitas (r11) menurut Guilford dalam Suherman (2003) ditunjukkan pada Tabel 1.

Tabel 1. Kriteria Derajat Reliabilitas

\begin{tabular}{ll}
\hline Derajat reliabilitas $\left(\mathrm{r}_{11}\right)$ & Kriteria \\
\hline $0,80<\mathrm{r}_{11} \leq 1,00$ & Sangat tinggi \\
$0,60<\mathrm{r}_{11} \leq 0,80$ & Tinggi \\
$0,40<\mathrm{r}_{11} \leq 0,60$ & Sedang \\
$0,20<\mathrm{r}_{11} \leq 0,40$ & Rendah \\
$0,00<\mathrm{r}_{11} \leq 0,20$ & Tidak reliabel \\
\hline
\end{tabular}

Pengaruh LKS berbasis problem solving terhadap keterampilan berpikir kreatif siswa dilihat dari perbedaan nilai rata-rata n-Gain antara kelas eks-perimen dan kelas kontrol. Rumus $n$-Gain menurut Hake (2002) adalah sebagai berikut:

$n-$ Gain $=\frac{\text { nilai prostes }- \text { nilai pretes }}{100-\text { nilai pretes }}$

Data pendukung pada penelitian ini yaitu analisis lembar keterlaksanaan pembelajaran menggunakan LKS berbasis problem solving dan analisis angket respon siswa terhadap pelaksanaan pembelajaran meng-gunakan LKS berbasis problem solving. Analisis keterlaksanaan pembelajaran menggunakan LKS berbasis problem solving dilakukan dengan langkah-langkah sebagai berikut: 
1) Menghitung jumlah skor yang diberikan oleh pengamat untuk setiap aspek pengamatan. Persentase ketercapaian menurut Sudjana (2005)

2) Menghitung rata-rata presentase ketercapaian untuk setiap aspek pengamatan dari dua orang pengamat.

3) Menafsirkan data dengan tafsiran harga persentase keterlaksanaan pembelajaran (RPP) sebagaimana pada tabel tafsiran berikut ini (Arikunto, 2006):

Tabel 2. Kriteria tingkat keterlaksanaan LKS

\begin{tabular}{|l|l|}
\hline Persentase & Kriteria \\
\hline $80,1 \%-100 \%$ & Sangat tinggi \\
\hline $60,1 \%-80 \%$ & Tinggi \\
\hline $40,1 \%-60,0 \%$ & Sedang \\
\hline $20,1 \%-40,0 \%$ & Rendah \\
\hline $0,0 \%-20,0 \%$ & Sangat rendah \\
\hline
\end{tabular}

Analisis data respon siswa terhadap pelaksanaan pembelajaran menggunakan LKS berbasis problem solving, dilakukan langkah-langkah berikut:

1. Menghitung jumlah siswa yang memberikan respon positif dan negatif

2. Menghitung persentase jumlah siswa yang memberikan respon positif dan negatif

3. Menafsirkan data dengan menggunakan tafsiran harga persentase sebagaimana Tabel.2

Uji hipotesis dilakukan dengan menggunakan software SPSS versi

17 for windows. Pertama yaitu Uji Normalitas ditentukan berdasarkan nilai sig. pada kolom Kolmogorov-Smirnov. Kedua yaitu Uji homogenitas dilihat dari nilai sig. pada kolom Test of Homogeneity of Variance.. Apabila sampel berdistribusi normal dan homogen, maka selanjutnya uji perbedaan dua rata-rata parametik pada $n$-Gain kelas eksperimen dan kelas kontrol dengan kriteria terima $\mathrm{H}_{0}$ jika nilai signifikan atau sig.(2tailed) $>0,05$ yang berarti tidak terdapat perbedaan antara rata-rata $n$-Gain keterampilan berpikir kreatif siswa di kelas eksperimen dan kelas kontrol, dan tolak $\mathrm{H}_{0}$ jika sebaliknya.

Selanjutnya uji independent sample t-test pada nilai pretes dan postes kedua kelas dengan kriteria terima $\mathrm{H}_{0}$ jika nilai signifikan atau sig.(2-tailed) > 0,05 yang berarti nilai pretes sama dengan nilai postes dan tolak $\mathrm{H}_{0}$ jika sebaliknya.Nilai $t_{\text {hitung }}$ yang diperoleh dari uji independent sample t-test tersebut, digunakan untuk perhitungan ukuran pengaruh (effectsize) dengan rumus menurut Jahjouh (2014) dengan kriteria effect size menurut Dincer (2015) seperti pada tabel berikut.

Tabel 3. Kriteria Effect Size

\begin{tabular}{ll}
\hline Effectsize $(\mu)$ & Kriteria \\
\hline$\mu \leq 0,15$ & Sangat kecil \\
$0,15<\mu \leq 0,40$ & Kecil
\end{tabular}




\begin{tabular}{ll}
$0,40<\mu \leq 0,75$ & Sedang \\
$0,75<\mu \leq 1,10$ & Besar \\
$\mu>1,10$ & Sangat besar \\
\hline
\end{tabular}

\section{HASIL DAN PEMBAHASAN}

Kegiatan pembelajaran meng-gunakan LKS berbasis problem solving beralokasi waktu tiga kali pertemuan. Pada pertemuan pertama dilakukan pretes pada kelas kontrol dan kelas eksperimen dengan alokasi waktu 45 menit. Sebelum soal digunakan untuk pretes-postes, soal terlebih dahulu diuji validitas dan reliabilitasnya. Uji kelayakan instrumen berguna untuk mengetahui seberapa layak suatu instrumen untuk dikembangkan, karena hal ini akan sangat berpengaruh terhadap suatu keterlaksanaan pem-belajaran menggunakan LKS berbasis problem solving. Pada uji validitas, soal akan dinyatakan valid apabila nilai $r_{\text {hitung }}$ yang diperoleh lebih besar dari $r_{\text {tabel }}\left(r_{\text {hitung }}>\right.$ $\mathrm{r}_{\text {tabel }}$ ) begitu pula halnya pada uji reliabilitas. Berdasarkan analisis validitas soal menggunakan software SPSS versi 17.0 diperoleh sebagai berikut :

Tabel 4. Hasil uji validitas butir soal essay

\begin{tabular}{|c|c|c|c|}
\hline $\begin{array}{c}\text { Butir } \\
\text { Soal }\end{array}$ & $\begin{array}{c}\text { Koefisien } \\
\text { Korelasi } \\
\left(\mathbf{r}_{\text {hitung }}\right)\end{array}$ & $\mathbf{r}_{\text {tabel }}$ & Kriteria \\
\hline 1 & 0,466 & 0,367 & Valid \\
\hline $2 \mathrm{a}$ & 0,521 & 0,367 & Valid \\
\hline $2 \mathrm{~b}$ & 0,667 & 0,367 & Valid \\
\hline 3 & 0,565 & 0,367 & Valid \\
\hline 4 & 0,488 & 0,367 & Valid \\
\hline 5 & 1 & 0,367 & Valid \\
\hline
\end{tabular}

Hasil perhitungan validitas soal pilihan essay tersebut menunjukkan bahwa nilai $r_{\text {hitung }}>r_{\text {tabel }}$, hal ini berarti instrumen tes tersebut valid. Reliabilitas instrumen tes ditentukan menggunakan rumus Alpha Cronbach dengan membandingkan $\mathrm{r}_{11}$ dan $\mathrm{r}_{\text {tabel }}$. Instrumen tes dikatakan reliabel jika $r_{11} \geq r_{\text {tabel }}$. Hasil perhitungan reliabilitas diperoleh nilai Alpha Cronbach $\left(\mathrm{r}_{11}\right)$ untuk soal essay diperoleh nilai Alpha Cronbach $\left(\mathrm{r}_{11}\right)$ sebesar 0,863 (reliabilitas sangat tinggi). Hal ini menunjukkan bahwa nilai $r_{11} \geq r_{\text {tabel }}$, sehingga instrumen tes dinyatakan reliabel.

Berdasarkan hasil uji validitas dan reliabilitas, soal tes telah dinyatakan valid dan reliabel, sehingga instrumen tes dinyatakan layak digunakan untuk mengukur keterampilan berpikir kreatif siswa.

Pada pertemuan kedua sampai ketiga dilakukan kegiatan pembelajaran menggunakan LKS berbasis problem solving pada kelas eksperimen dan LKS konvensional pada kelas kontrol pada materi larutan elektrolit dan non elektrolit. LKS berbasis problem solving memuat langkah-langkah model pembelajaran problem solving yang harus dilakukan oleh siswa yaitu mengorientasi masalah, mencari informasi, merumuskan hipotesis, menguji hipotesis dan menarik kesimpulan. Siswa 
dituntut berperan aktif, baik secara mandiri maupun kelompok untuk menemukan sendiri konsep materi yang dipelajari.

Setelah dilakukan penelitian, diperoleh data berupa nilai pretes dan postes. Nilai pretes dan postes tersebut kemudian digunakan untuk menghitung n-Gain. Perbandingan nilai rata-rata pretes dan postes antara kelas eksperimen dan kelas kontrol dapat dilihat pada gambar berikut:

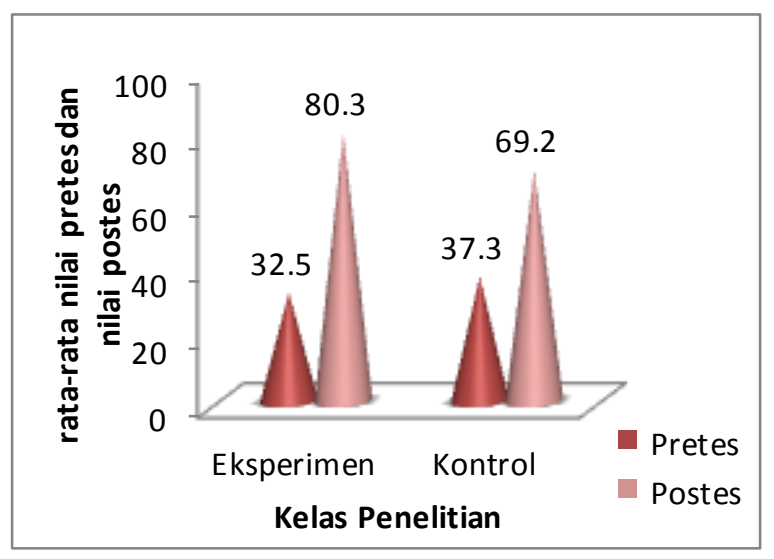

Gambar 1. Grafik perbandingan nilai rata-rata pretes dan postes pada keterampilan berpikir kreatif

Berdasarkan Gambar 1, terlihat bahwa nilai pretes dan postes di masing-masing sampel penelitian memiliki perbedaan yang signifikan, dimana nilai postes lebih tinggi daripada nilai pretes. Peningkatan pada kelas eksperimen lebih tinggi daripada kelas kontrol. Hal ini menunjukan bahwa keterampilan berpikir kreatif siswa di kelas eksperimen dan kontrol meningkat, namun peningkatan di kelas eksperimen lebih signifikan.

Perbandingan nilai rata-rata $n$-Gain yang diperoleh dari nilai pretes dan postes antara kelas eksperimen dan kelas kontrol dapat dilihat pada Gambar berikut :

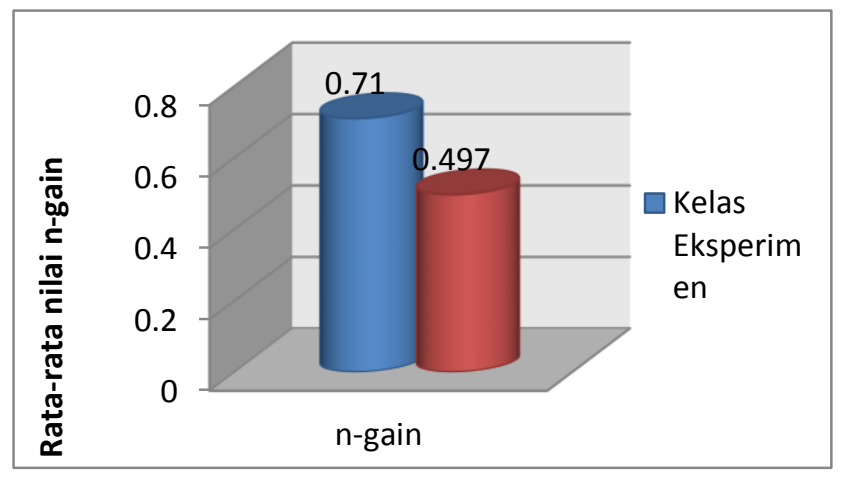

Gambar 2. Grafik perbandingan rata-rata $n$-Gain pada keterampilan berpikir kreatif

Berdasarkan Gambar 2, dapat dilihat bahwa nilai rata-rata $n$-Gain pada kelas eksperimen memiliki kriteria "tinggi" hal ini diperkuat dengan munculnya kemampuan berpikir kreatif siswa yang relatif tinggi dalam meng-hasilkan ide-ide baru yang berbeda dengan yang sudah ada yang dapat digunakan untuk membantu siswa dalam 
memberikan suatu keputusan yang berkualitas dalam menyelesaikan masalah-masalah yang ada dalam kehidupan sehari-hari. Pada kelas kontrol memiliki kriteria "sedang" hal ini diperkuat dengan munculnya kemampuan berpikir kreatif siswa yang relatif sedang dalam menghasilkan ide-ide baru yang berbeda dengan yang sudah ada yang dapat digunakan untuk membantu siswa dalam memberikan suatu keputusan yang berkualitas dalam menyelesaikan masalah-masalah yang ada dalam kehidupan seharihari. Berdasarkan hasil analisis data me-nunjukkan bahwa dengan menggunakan LKS berbasis problem solving ke-mampuan berpikir kreatif siswa lebih tinggi dibandingkan kelas kontrol, sehingga LKS berbasis problem solving berpengaruh dalam meningkatkan keterampilan berpikir kreatif siswa pada materi larutan elektrolit dan non elektrolit.

\section{Hasil Uji Normalitas dan Uji Homogenitas}

Uji normalitas digunakan untuk mengetahui apakah kedua kelompok sampel memiliki data yang berdistribusi normal atau tidak. Uji homogenitas digunakan untuk mengetahui apakah kedua kelompok sampel mempunyai varians yang homogen atau tidak. Hasil uji normalitas dan uji homogenitas di kelas eksperimen dan kelas kontrol dapat dilihat pada tabel berikut :

Tabel 5. Hasil uji normalitas

\begin{tabular}{|c|l|c|c|}
\hline \multirow{2}{*}{ Kelas } & $\begin{array}{l}\text { Aspek yang } \\
\text { diamati }\end{array}$ & $\begin{array}{l}\text { Nilai } \\
\text { Signifikan }\end{array}$ & Keterangan \\
\hline \multirow{2}{*}{ Eksperimen } & Pretes & 0,402 & Normal \\
\cline { 2 - 4 } & Postes & 0,317 & Normal \\
\cline { 2 - 4 } & $n$-Gain & 0,895 & Normal \\
\hline \multirow{2}{*}{ Kontrol } & Pretes & 0,285 & Normal \\
\cline { 2 - 4 } & Postes & 0,357 & Normal \\
\cline { 2 - 4 } & $n$-Gain & 0,427 & Normal \\
\hline
\end{tabular}

Berdasarkan tabel di atas terlihat bahwa pada kedua kelas tersebut nilai pretes, postes, dan $n$-gain memiliki nilai sig. dari kolmogorov-smirnov >0,05 sehingga keputusan uji terima $\mathrm{H}_{0}$ dan tolak $\mathrm{H}_{1}$ yang berarti data penelitian yang diperoleh berasal dari distribusi normal. Hasil uji homogenitas di kelas eksperimen dan kelas kontrol dapat dilihat pada tabel berikut :

Tabel 6. Hasil Uji Homogenitas

\begin{tabular}{|l|l|c|c|}
\hline & $\begin{array}{c}\text { Aspek } \\
\text { Nilai }\end{array}$ & $\begin{array}{c}\text { Nilai } \\
\text { Signifikan }\end{array}$ & Keterangan \\
\hline $\begin{array}{l}\text { Kelas } \\
\text { Kontrol }\end{array}$ & Pretes & 0,326 & Homogen \\
\cline { 2 - 2 } & Postes & & \\
\hline $\begin{array}{l}\text { Kelas } \\
\text { Ekperimen }\end{array}$ & Pretes & 0,845 & Homogen \\
\cline { 2 - 2 }$n$ & Postes & & \\
\hline$n$-Gain & $\begin{array}{l}\text { Nilai } \\
n \text {-Gain }\end{array}$ & 0,007 & $\begin{array}{c}\text { Tidak } \\
\text { Homogen }\end{array}$ \\
\hline
\end{tabular}


Berdasarkan tabel di atas terlihat bahwa pada kedua kelas nilai pretes dan postes, keduanya memiliki nilai sig. dari levene's test $>0,05$ sehingga keputusan uji terima $\mathrm{H}_{0}$ dan tolak $\mathrm{H}_{1}$ yang berarti bahwa data penelitian yang diperoleh berasal dari varians yang homogen, sedangkan $n$-Gain memiliki nilai sig. dari levene's test $<0,05$ sehingga keputusan uji tolak $\mathrm{H}_{0}$ dan terima $\mathrm{H}_{1}$ yang berarti bahwa data penelitian yang diperoleh berasal dari varians yang tidak homogen.

\section{Uji Perbedaan Dua Rata-rata}

Uji perbedaan dua nilai rata-rata $n$-Gain digunakan untuk mengetahui perbedaan antara hasil pembelajaran di kelas eksperimen dan kelas kontrol.

Tabel 7. Hasil Uji Perbedaan Dua Rata-rata $n$-Gain

\begin{tabular}{|c|c|c|c|c|}
\hline Kelas & $\mathbf{N}$ & Mean & $\begin{array}{c}\text { Std. } \\
\text { Deviation }\end{array}$ & $\begin{array}{l}\text { Sig. (2- } \\
\text { tailed) }\end{array}$ \\
\hline Eksperimen & 31 & 0.7097 & 0.14659 & \\
\hline Kontrol & 31 & 0.4961 & 0.24185 & 0,000 \\
\hline
\end{tabular}

Berdasarkan tabel di atas terlihat bahwa nilai sig. (2-tailed) sebesar 0,000 $<0,05$ sehingga tolak $\mathrm{H}_{0}$ dan terima $\mathrm{H}_{1}$ yang berarti bahwa terdapat perbedaan antara nilai rata-rata $n$-Gain siswa dikelas eksperimen dengan nilai rata-rata $n$-Gain siswa di kelas kontrol. Nilai rata-rata $n$-Gain siswa di kelas eksperimen lebih tinggi daripada nilai rata-rata $n$-Gain siswa di kelas kontrol. Hal ini menunjukkan bahwa LKS berbasis problem solving memiliki pengaruh terhadap peningkatan keterampilan berpikir kreatif.

\section{Ukuran Pengaruh (Effect Size)}

Berdasarkan hasil perhitungan uji effect size, diperoleh nilai effect size seperti disajikan pada Tabel 8 .

Tabel 8. Hasil uji ukuran pengaruh

\begin{tabular}{lllll}
\hline Data & Mean & df & $\mathbf{t}_{\text {hitung }}$ & $\boldsymbol{\mu}$ \\
\hline \multicolumn{2}{l}{ Kelas kontrol } \\
Pretest & 37.2581 & & & \\
& & 60 & -8.867 & 0.75 \\
Posttest & 69.2258 & & & \\
\hline
\end{tabular}

Kelas eksperimen

Pretest $\quad 32.5161$

Posttest $\quad 80.2903 \quad 60 \quad-19.663 \quad 0.93$

Berdasarkan Tabel 8, dapat dilihat nilai effect size untuk kelas eksperimen memiliki kriteria "besar" dan kelas kontrol memiliki kriteria "sedang". Hasil perhitungan tersebut me-nunjukkan bahwa 93\% keterampilan berpikir kreatif siswa pada kelas eksperimen dipengaruhi oleh pem-belajaran menggunakan LKS berbasis problem solving sedangkan $75 \%$ keterampilan berpikir kreatif siswa pada kelas kontrol 
dipengaruhi oleh pem-belajaran menggunakan LKS konvensional. Berdasarkan hasil pengujian hipotesis dan perhitungan effect size dapat dikatakan bahwa LKS berbasis problem solving memiliki pengaruh yang lebih besar dalam meningkatkan keterampilan berpikir kreatif siswa daripada menggunakan LKS konvensional. Hal ini sejalan dengan penelitian Ardiani (2017) menyatakan bahwa LKS berbasis problem solving dapat meningkatkan keterampilan berpikir kreatif siswa.

Penelitian yang telah dilakukan ini dapat membuktikan bahwa pembelajaran dengan menggunakan LKS berbasis problem solving pada materi larutan elektrolit dan non elektrolit berpengaruh terhadap keterampilan berpikir kreatif siswa khususnya keterampilan berpikir lancar, luwes, orisinil dan evaluatif. Perbedaan mendasar yang menjadi faktor utama sehingga menyebabkan rata-rata n-gain siswa kelas eksperimen dengan menggunakan LKS berbasis problem solving lebih tinggi daripada kelas kontrol.

Hasil kesimpulan yang diperoleh didukung dengan adanya hasil analisis lembar observasi keterlaksa-naan LKS berbasis problem solving dan perhitungan angket respon positif siswa. Adapun hasil perhitungan analisis lembar keterlaksanaan LKS berbasis problem solving disajikan pada tabel berikut ini:

Tabel 9. Hasil analisis data ke-terlaksanaan pembelajaran menggunakan LKS ber-basis problem solving

\begin{tabular}{|c|c|c|}
\hline $\begin{array}{c}\text { Pertemuan } \\
\text { ke- }\end{array}$ & $\begin{array}{c}\text { Aspek } \\
\text { Pengamatan }\end{array}$ & $\begin{array}{c}\text { Persentase } \\
\text { Ketercapaian } \\
(\%)\end{array}$ \\
\hline \multirow{4}{*}{1} & Sintak & $70.00 \%$ \\
\hline & Sistem Sosial & $75.00 \%$ \\
\hline & Prinsip reaksi & $81.25 \%$ \\
\hline & $\begin{array}{l}\text { Rata-Rata } \\
\text { Pertemuan } 1 \\
\end{array}$ & $75.00 \%$ \\
\hline \multirow{4}{*}{2} & Sintak & $80.00 \%$ \\
\hline & Sistem Sosial & $81.25 \%$ \\
\hline & Prinsip reaksi & $87.50 \%$ \\
\hline & $\begin{array}{l}\text { Rata-Rata } \\
\text { Pertemuan } 2 \\
\end{array}$ & $83.00 \%$ \\
\hline \multirow{4}{*}{3} & Sintak & $85.00 \%$ \\
\hline & Sistem Sosial & $93.75 \%$ \\
\hline & Prinsip reaksi & $87.50 \%$ \\
\hline & $\begin{array}{l}\text { Rata-Rata } \\
\text { Pertemuan } 3\end{array}$ & $89.00 \%$ \\
\hline \multicolumn{2}{|c|}{ Rata-Rata Keterlaksanaan } & $82.00 \%$ \\
\hline
\end{tabular}

Berdasarkan Tabel 9 terlihat bahwa rata-rata persentase ke-terlaksanaan pembelajaran kimia meng-gunakan LKS berbasis problem solving dari pertemuan 1 sampai 3 semakin meningkat, jika dirata-ratakan secara keseluruhan diperoleh hasil $82.00 \%$ memenuhi kriteria "sangat tinggi". Hal ini menandakan bahwa ke-terlaksanaan pembelajaran kimia menggunakan LKS berbasis problem solving sangat baik digunakan untuk melatih keterampilan berpikir kreatif siswa.

Adapun hasil perhitungan analisis data respon siswa terhadap pelaksanaan pembelajaran disajikan pada tabel 10. berikut ini : 
Tabel 10. Hasil analisis data respon siswa terhadap pelaksanaan pembelajaran

\begin{tabular}{|c|c|c|c|c|}
\hline No & \multicolumn{2}{|l|}{ Aspek } & $\begin{array}{l}\text { Presentase respon siswa } \\
(\%)\end{array}$ & Kriteria \\
\hline \multirow[t]{5}{*}{1.} & \multirow{5}{*}{$\begin{array}{l}\text { Perasaan } \quad \text { siswa } \\
\text { terhadap: }\end{array}$} & Materi pembelajaran & $89,65 \%$ & Sangat tinggi \\
\hline & & LKS & $96,65 \%$ & Sangat tinggi \\
\hline & & Suasana belajar & $96,65 \%$ & Sangat tinggi \\
\hline & & Cara guru mengajar & $96,65 \%$ & Sangat tinggi \\
\hline & & Cara guru merespon & $96,65 \%$ & Sangat tinggi \\
\hline \multirow[t]{5}{*}{2.} & \multirow{5}{*}{$\begin{array}{ll}\text { Pendapat } & \text { siswa } \\
\text { komponen: } & \end{array}$} & Materi pembelajaran & $100,00 \%$ & Sangat tinggi \\
\hline & & LKS & $100,00 \%$ & Sangat tinggi \\
\hline & & Susana belajar & $82,75 \%$ & Sangat tinggi \\
\hline & & Cara guru mengajar & $100,00 \%$ & Sangat tinggi \\
\hline & & Cara guru merespon & $96,65 \%$ & Sangat tinggi \\
\hline 3. & \multicolumn{2}{|c|}{ Minat siswa terhadap pembelajaran } & $96,65 \%$ & Sangat tinggi \\
\hline \multirow[t]{7}{*}{4.} & \multirow{7}{*}{$\begin{array}{l}\text { LKS dan media } \\
\text { yang diguna-kan }\end{array}$} & Pemahaman bahasa & $89,65 \%$ & Sangat tinggi \\
\hline & & Penampilan LKS & $100,00 \%$ & Sangat tinggi \\
\hline & & Pemahaman isi LKS & $86,20 \%$ & Sangat tinggi \\
\hline & & Kemenarikan wacana & $86,20 \%$ & Sangat tinggi \\
\hline & & $\begin{array}{l}\text { Kemudahan mempelajari } \\
\text { materi }\end{array}$ & $96,65 \%$ & Sangat tinggi \\
\hline & & $\begin{array}{l}\text { Pemahaman } \\
\text { pembelajaran dengan } \\
\text { LKS }\end{array}$ & $93,10 \%$ & Sangat tinggi \\
\hline & & $\begin{array}{l}\text { Ketertarikan } \\
\text { pemanfaatan } \\
\text { webpage/webblog }\end{array}$ & $100,00 \%$ & Sangat tinggi \\
\hline \multicolumn{3}{|c|}{ Rata-rata persentase respon siswa } & $95,00 \%$ & Sangat tinggi \\
\hline
\end{tabular}

Berdasarkan Tabel 10 terlihat bahwa rata-rata persentase respon siswa terhadap penggunaan LKS berbasis problem solving diperoleh hasil 95,00\% memenuhi kriteria "sangat tinggi" maka dapat dikatakan bahwa respon siswa terhadap penggunaan LKS berbasis problem solving sangat tinggi.

\section{KESIMPULAN}

LKS berbasis problem solving memiliki pengaruh yang besar dalam meningkatkan keterampilan berpikir kreatif siswa. Hal tersebut dapat ditunjukkan melalui perbedaan yang signifikan antara nilai $n$-Gain keterampilan berpikir kreatif pada kelas eksperimen dan kelas kontrol, dimana kelas eksperimen memilki rerata nilai $n$-Gain keterampilan berpikir kreatif yang lebih besar daripada kelas kontrol. Pengaruh LKS berbasis problem solving dalam meningkatkan keterampilan berpikir kreatif siswa juga dilihat dari hasil observasi keterlaksanaan pem-belajaran menggunakan LKS berbasis problem solving yang berkategori "sangat tinggi" dan respon siswa terhadap pembelajaran menggunakan LKS berbasis problem solving yang berkategori "sangat tinggi" sehingga dapat membantu meningkatkan ke-terampilan berpikir kreatif siswa.

\section{DAFTAR RUJUKAN}

Abidin, Y. 2016. Desain Sistem Pembelajaran dalam Konteks Kurikulum 2013. Refika Aditama. Bandung. 
Ardiani, F., Rudibyani, R.B. dan Efkar, T. 2017. Pengembangan LKS Berbasis Problem Solving Untuk Meningkatkan Keterampilan Berpikir Kreatif Materi Asam Basa. Journal Pendidikan dan Pembelajaran kimia. Pogram Studi Pendidikan Kimia FKIP Unila, 7(1): Hal 91-103.

Arikunto, S. 2006. Prosedur Penelitian:

Suatu Pendekatan Praktik. Rineka

Cipta. Jakarta.

Caprioara, D. 2015. Problem Solving- Purpose a Means of Learning Mathematics in School . Romania Journal of Social and Behavioral Science University of Ovidius Constanta, 191: 1859-1864.

Celikler, D. 2010. The effect of work-sheets Developed For The Sub-ject Of Chemical Compounds On Student Achievement And Permanent Learning. Internati-onal Journal Of Educology, (1): 42-51.

Depdiknas. 2008. Panduan Pengembangan Lembar Kerja Siswa. Depdiknas. Jakarta.

Dincer, S. 2015. Effect of Computer Assisted Learning on Students'Achievement in Turkey: a Meta-Analysis. Journal of Turkish Science Education, 12(1), 99-118.

Fadiawati, N. 2014. Ilmu Kimia Sebagai Wahana Mengembang-kan Sikap dan Keterampilan Berpikir. Eduspot Magazine (Edisi Maret-Juni): 8-9.

Fraenkel, J. R., N. E. Wallen, \& H. H. Hyun. 2012. How to Design and Evaluate Research in Education. McGrow-Hill. New York.

Hake, R. R. 2002. Reliatonship of Individual Student Normalized Learning Gains in Mechanis with Gender, High School Physics, dand Pretest Scoreon Mathematics and Spatial Visualization. Physics Education Research Conference. Diakses pada tanggal: 05 November 2018

Hardianto, D. 2012. Pengembangan Media Pembelajaran Berbasis Komputer. Jurnal UNY Majalah Ilmiah Pembelajaran Edisi Khusus, 3(2): 7-9.

Hidayat, S dan Majid, A. 2013. Pengembangan Kurikulum Baru. PT Rosda Karya. Bandung

Jahjouh, Y. M. A. 2014. The Effectiveness of Blended E-Learning Forumin Planning for Science Instruction. Journal of Turkish Science Education,11(4), 3-16

Muliawan, J.S. 2016. Model Pem-belajaran Spektakuler. Ar-Ruzz Media. Yogyakarta.

Munandar, U. 2014. Pengembangan Kreativitas Anak Berbakat. Rineka Cipta. jakarta.

Muzaki, A. 2014. Meningkatkan Ke-mampuan Berfikir Kritis dan Kreatif Matematik Siswa MTs Negeri 1 Jonggat Dengan Pembelajaran Tasc (Thinking, Actively dan Social Context) Pada Materi Segitiga. Jurnal Media Pendidikan Matematika. 2 (1): 197- 202.

Salirawati, D. 2010. Profesionalisme Penelitian dan Pendidik dalam Riset dan Pembelajaran Kimia yang Berkualitas dan Berkarakter. Optimalisasi Pendidikan Nilai/Karakter dalam Pendidikan Kimia Masa Depan. Seminar Nasional Kimia 112.

Sudjana. 2005. Metoda Statistika. Tarsito. Bandung.

Wijaya, E. Y., Sudjamat, D. A., \& Nyoto, A. 2016. Transformasi Pendidikan Abad 21 Sebagai Tuntutan Pengembangan Sumber Daya Manusia Di Era Global.

Prosiding Seminar Nasional Pendidikan Matematika, Volume 1 Tahun 2016. Universitas Negeri Malang 